\title{
Establishing Program Standards to Meet the Needs of Postsecondary Trade and Industrial Education
}

\author{
Beno Rubin \\ Tidewater Community College \\ Michael F. Kosloski \\ Old Dominion University \\ Roberto Loya \\ Old Dominion University
}

\begin{abstract}
The focus of this study was to develop standards that can be used for establishing and assessing high-quality postsecondary trade and industrial programs. A four-round Delphi technique was used to generate consensus regarding program standards. The panel of experts, comprised of postsecondary administrators of trade and industrial programs, was used to determine which program standards should guide the development and assessment of high-quality trade and industrial education programs. The result was a list of 17 standards and descriptions. The standards included Academic Integration, Advisory Committee, Curriculum, Employer Feedback, Faculty Qualifications, Meaningful Employment, Placement Rates, Program Design, Program Review, Safety, Soft Skills, Student Achievement of Industry Credentials, Student Assessment, Student Advancement, Student Remediation, and Tools and Equipment. Postsecondary administrators can use the results to develop and assess existing programs, as well as to guide the design of new programs that meet industry labor needs.
\end{abstract}

Keywords: program standards, community college program standards, postsecondary program standards, trade, and industrial education

The need for a skilled labor force has become more apparent in today's economy. Postsecondary educational institutions such as community colleges have been tasked with preparing the current and future mid-skilled workforce (Yarnall, 2014). Many students pursue a baccalaureate degree because they believe high school career and technical education (CTE) programs restrict their income potential relative to college graduates (Bailey et al., 2004). However, a four-year degree does not always guarantee a job, and these graduates often find themselves in debt due to the student loans required to obtain their degrees. Many college graduates must go back to school to retrain for a technical skill to pursue a career (Grubb, 1996). Some four-year college graduates return to community college CTE programs to receive training and increase their earning potential (Symonds et al., 2011).

In the $21^{\text {st }}$ century, there has been greater emphasis placed on high school career preparation programs as businesses look to update the skills of their prospective workers to stay 
current with changing trends in industry (Dougherty \& Bakia, 2000). The combination of industry requirements for skilled labor and individuals seeking employment or retraining creates a climate in which postsecondary institutions can take a lead role in providing the necessary training. Postsecondary education institutions are not replacing high school trade and industrial programs, but rather are providing the necessary training for highly specific industry credentials and technical skill development for new and incumbent workers (Jacobs, 2001). Postsecondary institutions, particularly community colleges, are in an advantageous position to offer the training that industry requires while addressing changing economic needs (O'Banion, 2019). Developing programs that continue to directly address industry's evolving needs will create new pathways for those seeking employment and better preparing them for the workforce, as well as benefitting both industry and the local economy.

The question that arises from this discussion is: How does industry ensure that schools are providing workers who can perform in the workplace? Many K-12 educational programs are required by law to meet state standards for student achievement. Postsecondary institutions must also meet accrediting agency standards. However, program standards for postsecondary trade and industrial programs can vary amongst the different programs if they exist at all. Program standards can help trade and industrial programs by providing a framework for program design, development, and assessment. Training programs that meet agreed-upon standards, because of evaluation processes that involve industry, could validate programs that are of high-quality, and which develop skilled workers that meet the needs of employers. As a result, this study was designed to identify standards for designing and assessing postsecondary trade and industrial programs. Once established, institutions can use them to develop and assess their programs and thus improve the delivery of trade and industrial education, thereby improving the process of preparing employable workers in the industry.

\section{Theoretical Framework}

Isology, or the science of standards, is a phrase originally coined by the Center for Global Standards Analysis (Center for Global Standard Analysis [CGSA], 2008). A standard is an established reference, and the process of creating standards primarily requires practical skills (CGSA, 2008). As stated by Arthur (1988), the utilization of standards increases compatibility, interchangeability, interoperation, and usability. The effects of standards are wide ranging and include expanded communications, increased quality, decreased costs, increased trade, increased uniformity, new markets, information dispersion, market control, and regulation. This study places the utmost importance on quality and uniformity.

Standardization may occur by accident, assumption, convention, committee, or sanction (Hayek, 1973). Because practical skills are constantly changing, the standardization process is ongoing and is therefore evolutionary (CGSA, 2008). The process also generally necessitates that each participant in the standardization process must find their own perspective represented before they can agree to a new standard (Krechmer, 2006). Once standards have been developed, the epistemology behind standards can direct future endeavors toward the nature of such knowledge, its possibility, scope, general basis, and justification (Honderich, 1995). While some programs, particularly those developed with collaboration from individual industrial partners, may desire organizationally specific content, the creation of such standards in trade and industrial education programs can lead to more effective and streamlined programs with 
consistency and compatibility between programs.

\section{Review of Literature}

Background and Significance. The need to have program standards for trade and industrial education is not a new idea. Educational programs undergo assessments at various levels, using standards to benchmark agreed upon criteria for providing sound education or training results. With the passage of the Vocational Education Amendments of 1968, Public Law 90-576, evaluation became a mandatory part of the states' responsibility of ensuring positive outcomes of secondary and postsecondary occupational education programs (Wentling, 1980). The Vocational Education Amendment of 1976 created stronger evaluation guidelines, which required vocational education programs to report on the ability of their students to obtain employment and measure the quality of their training by employers (McCaslin \& Headley, 1993).

Other federal government initiatives have established training standards. The Job Training Partnership Act of 1982 required the use of performance measures and standards, such as placement and retention in unsubsidized programs, earnings, and reductions in public assistance, to determine the effectiveness of an employment and training program. The Carl D. Perkins Vocational and Applied Technology Education Act of 1990 reinforced the use of standards as school systems revised their evaluation methods. This Act also required states to develop core standards and performance measures for secondary and postsecondary vocational programs (McCaslin \& Headley, 1993).

In 1983, the National Automotive Technicians Education Foundation (NATEF) developed a set of standards that outlined not only curriculum standards, but program standards as well (Lundquist, 2000). These standards defined how secondary and postsecondary automotive technology programs meet industry standards (National Automotive Technicians Education Foundation, 2012). The NATEF standards are one of the few available for trade and industrial programs. They are similar in structure to the 1985 Standards for Technology Education Programs (American Industrial Arts Association, 1985). However, those standards were written specifically for secondary schools. In 2018, NATEF merged with the Automotive Youth Educational Systems (AYES) and became the ASE Education Foundation. The latest standards are broken down into three subcategories, all founded on the 1985 standards (ASE, 2018).

Recommendations have been made to enhance program standards so they can be more widely used by trade and industrial programs. The National Skills Standards Board (NSSB) designed a system to develop and implement skill standards for training programs (Willis, 1995). However, the standards developed were subject specific.

In 1995, the National Center for Research in Vocational Education released a report that detailed recommended changes to the Carl D. Perkins Applied Technology and Vocational Education Act of 1990. One of the areas of focus in its recommendations was the improvement of measures and standards (Stecher et al., 1995). Most of these recommendations focused on student outcomes, not program improvement.

More studies need to be conducted related to career and technical education with specific emphasis on assessment (Lambeth et al., 2009). The National Career and Technical Education Research Agenda Model outlines how research should be conducted in the various career and technical education areas (Lambeth et al., 2009). However, there is little discussion about 
specific standards to measure program quality.

Postsecondary Trade and Industrial Education. According to the Association of Career and Technical Education (2021), trade and industrial education is defined as a CTE program that "...prepares people for careers in a variety of trades, including carpentry, masonry, electrical and construction management, automotive technology, heating, ventilation and air conditioning systems, computer-aided drafting and manufacturing, and cosmetology" (para. 2). While prominent in the high school environment, postsecondary trade and industrial education also plays an integral role in preparation for those wishing to enter a career in a skilled trade, particularly adult learners.

Federal legislation has changed along with postsecondary institutions to provide workforce education for the adult learner. Community colleges, proprietary schools, corporate schools, and four-year institutions have provided occupationally specific education that is part of an education continuum beginning with the secondary level (Bragg, 2001; Kim et al., 2021). The differences lie in the mission of each type of school. Historically, four-year institutions offer a wide range of subjects for students to choose from, some of which do not provide them with jobspecific skills. Other types of schools generally have career training as a primary goal, as they typically provide training for specific industries and communities. However, the perception of postsecondary occupational education has often been considered inferior education relative to academic or transfer programs (Gauthier, 2020; Kelly \& Price, 2009).

By aligning themselves with industry, postsecondary institutions are better able to prepare their students for their role in the workforce. The Bureau of Labor Statistics determined that 70 percent of job openings between 2001 and 2010 did not require a four-year degree. As a result, postsecondary institutions must identify which student outcomes best prepare them for a skilled trade (Soares, 2010).

Some schools offer trade and industrial education through non-credit courses. Community colleges engage in contract training to meet the specific needs of industry and to deliver this instruction in a short timeframe (Bryant, 2014). Workforce development programs can support industry as well as their related economic sectors. The White House Summit on Community Colleges (Biden, 2011) recommended that workforce development programs should prepare workers for positions within key economic sectors.

Many students attend institutions that emphasize career and technical education in hopes that their training will lead to a better job and higher wages (Johnson et al., 2019). Often, students who enroll in trade programs are considered mid-skilled workers (Kim et al., 2021; Torraco, 2008). They primarily receive their training from technical colleges, community colleges, proprietary schools, and privately funded job training programs. Students in these programs benefit from lab- and work-based learning that can be directly applied to their job. Other students enroll in postsecondary school to upgrade their job skills and are not interested in achieving a credential (Hirschy et al., 2011). Noncredit occupational training at the postsecondary level is an important contributor to nontraditional pathways through higher education (Xu \& Ran, 2020)

Innovative postsecondary institutions frequently have strong partnerships with industry, government, and education (Brown, 2018). Programs that work in cooperation with these entities can develop trade programs that provide competencies for students that can be applied to the business community. Community colleges, when providing professional development for businesses, can provide credentials that enhance specific occupational training (Schmidtke, 
2012). Interaction with local employers, along with a curriculum driven by the labor market, helps to establish a successful program (Hereford, 2005). The postsecondary institution must have an internal understanding of a business culture when engaging in partnerships with business and industry (United States Department of Education, 2012).

Standards. Standards can be defined as established references (CGSA, 2008; Krechmer, 2006). A major component of a quality CTE program is its ability to meet accrediting standards set by industry and accrediting boards. These standards provide the framework with which the technical program will operate. They also guide the program to ensure the outcome is a skilled worker in the trade. The Perkins Act of 2006 defines the requirements that a CTE program must follow to receive federal funding (Brustein, 2006; Hyslop, 2018). However, there is not a commonly accepted definition of standards that were developed by business, state educators, and the federal government (Losh, 2000). Additionally, standards in postsecondary CTE focus on occupational skill standards to satisfy Perkins's requirements (Merkley \& Johnston, 2007).

The development of skill standards emerges from both education and industry (Willis, 1995). In education, competencies are compiled and used to develop curriculum, instructional activities, and evaluation criteria (Aragon et al., 2004). Industry approaches skill standards differently. Many industries driven skill standards are based on the issuance of a skill-based credential (Aragon et al. 2004). Often, industry representatives want a clearer understanding of what the standards, certification, and training represent because "they fear that national skill standards mean government intervention in their business and industry" (Anderson \& Kosarek, 1997, p. 22). The 2004 National Assessment of Vocational Education (NAVE) found that employers collaborated with postsecondary institutions to develop curriculum for their local needs rather than follow national standards (Silverberg et al., 2004).

Assessment Methods. While standards describe the knowledge, skills, and behaviors critical to an occupational area, assessments determine the level at which those standards are achieved. Assessments can be conducted on a national scale, at the program level, on a specific aspect of a program, or on student achievement. Assessment of CTE can be classified into two themes: assessment of learning and performance and assessment of the education process and design (Beltram, 2011; Brown, 1997). Identifying what to assess is critical to determine the overall outcome of the training program.

Assessment by industry is one method a trade and industrial program can utilize to determine if it is meeting the defined standards. Surveying local employers can reveal both the strengths and weaknesses of the program. A school's business partners can be brought in to evaluate the program based on industry's needs and goals (Aragon et al., 2004; Zinser, 2003). When the workplace becomes the curriculum (as in work-based learning), the relationship of assessment will shift from education to employers (Abeysekera, 2006). This may be a desired outcome if the program includes processes and knowledge based in the workplace.

Workforce development programs may have varying program outcomes for secondary and sub-baccalaureate postsecondary training. Mullin (2012) stated that the assessment model for workforce development training has metrics that can be applied to the evaluation of educational programs. The metrics are earnings, placement, licensure, industry certification, and debt measures.

Assessment of a community college program that offers a certificate in a specific area has traditionally been conducted by collecting data on the number of students who receive the certificate. However, many students in the community college often leave college without the certificate once they have achieved the job skills they desire and obtain better employment 
Journal of Research in Technical Careers

Journal of Research in Technical Careers December 2021, Vol. 5, No. 2

(C) Author(s)

(Lohman \& Dingerson, 2005). Lohman and Dingerson (2005) recommended an alternative method to assess these programs by the number of students that have met their personal training goal. Several states (e.g., Indiana, Oklahoma, Kentucky, Wisconsin) have recognized this challenge and passed legislation to improve postsecondary attendance and completion (Hirschy et al., 2011).

An emerging trend that ensures a program meets current standards is to align it with the desired workplace outcomes by performing a needs assessment of local businesses (Aragon et al., 2004; Rojewski, 2002). Another method to align a program to workplace outcomes is through occupational certificates, which may include board and licensing exams (Baird et al., 2020). However, assessment of the program may be more difficult if they do not have an external accreditation requirement (Torraco, 2008). Program advisory committees may be yet another source of program assessment. Through a program review, members can evaluate a program's curriculum, assess graduate quality, and make recommendations for future course offerings that will directly impact the program's ability to align with industry standards (Kerka, 2002).

State agencies and individual schools and school districts often engage in forms of program assessment. For example, the Peoria Unified School District worked with over 130 stakeholders, including teachers and members of local businesses, to develop an assessment system for their secondary CTE programs (Beltram, 2011). Some schools have adopted the Postsecondary Education Research Center's (PERC) evaluation tool to determine the effectiveness of their dual enrollment transition programs. This evaluation tool has ten areas of assessment which include program planning, staffing, administration, student planning, student activities, employment, self-determination, interagency collaboration, monitoring, and evaluation (Grigal et al., 2012). The St. Louis County Special School District developed Program Status Indicators to assess their CTE programs. The five assessment factors they used were placement, enrollment, advisory committees, certification, and occupational outlook (Gaal \& Trafton, 2009).

Postsecondary institutions align with various regional accrediting agencies. One agency, the Council on Occupational Education (COE), provides accreditation for various types of postsecondary schools to include military and government training programs. The COE awards accreditation to institutions that offer CTE programs as well as programmatic accreditation and is recognized by the U.S. Department of Education (Council on Occupational Education, 2012). They assess programs for accreditation based on five main factors that include admissions and student services, programs, instruction, program outcomes, and distance education.

Identifying High Quality Training Programs. Once a training program has met defined standards through the assessment process, it can be declared a quality program. At this point, the level that the program exceeded standards would help to define them as high quality or exemplary. The literature varies greatly on how to recognize exemplary programs, but all are benchmarked by meeting defined standards.

In 2001, the National Research Center for Career and Technical Education identified critical factors for classifying an exemplary secondary program: industry credentialing, use of data for program improvement, integration of academic and technical skills, and partnerships with business and industry (National Dissemination Center for Career and Technical Education, 2001). The No Child Left Behind Act of 2001 defined a high-quality program as a program that can improve a learning outcome, utilize objective data, develop measurable goals and objectives, and implement scientifically based activities that meet identified needs.

The National Research Center for Career and Technical Education followed this discussion with the release of a rubric for identifying exemplary secondary level CTE programs 
in 2002 (National Dissemination Center for Career and Technical Education, 2002). This rubric consisted of four main criteria that included program goals, program content, standards, and partnerships/reform. Each criterion contained sub-sections that were to be scored on a four-point scale where one indicated a struggling program and four indicated an exemplary program (National Dissemination Center for Career and Technical Education, 2002). This system generated quantitative data regarding the success of a program.

Three business awards, Malcolm Baldrige National Quality Award, the Deming Application Prize, and International Organization for Standardization (ISO) 9000 Registration, can be used as a blueprint to assess quality vocational education programs (Brown, 1997). The Baldrige Award focuses on customer satisfaction and retention, the Deming Prize rewards businesses who apply quality control methods based on statistical data, and the ISO 9000 Registration recognizes companies that meet the ISO's quality standards (Izadi et al., 1996). The requirements and framework for these awards can be found in educational recognition awards throughout the country.

\section{Purpose of the Study}

The purpose of this study was to develop standards that can be used for establishing exceptional postsecondary trade and industrial education program. The research objectives that were developed to guide this study were:

$\mathrm{RO}_{1}$ : Develop a set of program standards to be used to establish high-quality

postsecondary trade and industrial education programs.

RO2: Develop descriptors that can be used to assess achievement of high-quality postsecondary trade and industrial education programs.

\section{Methods}

Research Design. The research method selected for this study was the Delphi technique, which employed a four round sequence to determine the standards that can be used to develop a high-quality postsecondary trade and industrial education program. The Delphi technique provided a system and method of data collection using a panel of experts within this field (Powell, 2003). The Delphi technique consists of a series of surveys where the panelists receive feedback based on the previous rounds to allow them to reevaluate their responses. This method provides a controlled interaction between the researcher and the participants and avoids the disadvantages of a round table discussion (Parente \& Anderson-Parente, 2011). Using a survey method, panelists were asked to identify standards, including their descriptions, for establishing high-quality trade and industrial education programs in the first round. The second round provided the panelists the opportunity to add any standards they felt were missing from the Round 1 list. The panel was asked to rate the importance of the standards in two subsequent rounds to determine consensus.

The Delphi technique can obtain opinions and consensus from a diverse group of expert participants (Stitt-Ghodes \& Crews, 2004). According to Williams and Webb (1994), "When consensus is achieved, it can be argued that there is evidence of concurrent validity, in that the experts themselves have both identified and agreed upon the requisite skills" (p. 182). While reliability is more difficult to verify using the Delphi method, when proper procedural guidelines have been followed, the scientific community readily accepts this method as a reliable and valid 
technique (Landeta, 2005). The results from the panelists helped to form a consensus on standards that were used for designing and assessing high-quality postsecondary trade and industrial education programs.

Delphi Panel. The criteria for the selection of panelists were that prospective participants were postsecondary administrators/directors responsible for trade and industrial programs at their postsecondary institutions. Using a variety of resources, including professional organizations and Web searches, the researchers compiled a list of postsecondary trade and industrial administrators from institutions with multiple trade and industrial programs, ensuring that all eight areas of trade and industrial education were represented. Selected administrators were invited to participate. The administrators who were invited and responded were from programs located throughout the United States. The researcher assembled a purposive sample, resulting in a panel of 16 participants, two for each trade and industrial education area, to ensure a homogenous group with enough respondents.

To ensure that the responses from each participant were not influenced by other experts, the names of the panelists were not revealed to the others who volunteered for this study. The panelist information that was collected included the trade and industrial programs they are responsible for and the number of years in their position. To ensure consistent interactions with the panelists, the lead researcher was the only person contacting the participants during the study.

Procedures and Data Analysis. Before the start of Round 1, a pilot study with four administrators within the researcher's home state was undertaken to determine if the initial survey sufficiently yielded the desired responses before it was provided to the panelists. The pilot study participants completed the survey and provided feedback regarding the quality and relevancy of the instrument. The administrators completed the survey and were satisfied with the quality of the survey and questions. As a result, no additional changes were made to the survey instrument. Only four administrators were invited to participate, as the pool of administrators that met the criteria was limited.

Once the pilot study was completed, the prospective Delphi panelists received a letter asking for their willingness to participate in the study. The panelists who agreed to participate were contacted via e-mail and provided with the purpose and timeline for the study. In Round 1 the panelists received an overview that explained the purpose of the study and the directions on how to proceed with the survey. This correspondence provided a definition for standard, as well as a definition of a description of a standard, to assist panelists when making their decisions on the survey. The panelists were asked to complete an anonymous online survey that asked the panelists for two things. First, they were asked to identify which of the eight trade and industrial areas they represented. Multiple selections were permitted. Second, they were asked to list two standards, along with the descriptions, that they felt helped to define a high-quality postsecondary trade and industrial program.

A review board of three individual college administrators not associated with the study was sent an invitation to assist the researchers in categorizing the responses. These review board members had experience with program standards but did not work for the researchers. The review board analyzed the results from the first round of the survey and categorized the responses by standard similarities. The review board also determined common descriptions for each standard. They returned the reviewed standards and descriptions to the researchers in preparation for Round 2. The researcher then refined the standards and descriptions to ensure similarities in structure and voice. The result was a list of 26 standards, which were reduced to 
six standards after the categorization by the review board.

In Round 2 the panelists were e-mailed instructions along with the list of edited standards and descriptions generated from Round 1 . The panelists were asked to identify additional standards that they felt may have been missing from the Round 1 listings. The researchers edited the new standards and descriptions by applying the same methods used in Round 1.

Round 3 was designed to initiate the process of drawing consensus on the standards. The panelists were e-mailed the compiled list of standards generated in Round 2 and were asked to rate the standards using a 5-point Likert scale, with 5 being strongly agree and 1 being strongly disagree. The panelists e-mailed the completed surveys back to the lead researcher.

Using measures of central tendencies, the ratings from all the surveys were compiled and analyzed. The scores were sorted to determine the mean, median, standard deviation, and interquartile range $(I Q R)$. The $I Q R$ was used to determine the strength of consensus among the panelists for each standard. An $I Q R$ less than or equal to 2.0 and a mean score greater than 3.50 would indicate agreement among the panelists for the standard and it would be retained. The researcher chose these thresholds as they have been supported by other studies (Kosloski \& Ritz, 2016; Roberts, 2013). These studies had similar measures and scales relative to this research study.

Round 4 was designed to further the process of drawing consensus on the standards identified by the panelists. The researcher e-mailed the panelists the list of standards generated through the previous round, excluding any standards that were eliminated. The panelists were also given the group mean, median, $I Q R$, and standard deviation of the standards, along with their individual rating scores. With this knowledge, they were then asked to review and re-rate the standards and e-mail their results back to the researcher.

Round 4 results included calculations for the mean, median, standard deviation, $I Q R$, and coefficient of variation $(C V)$. A mean score greater than 3.50 and an $I Q R$ less than or equal to 2.0 would indicate consensus. $C V$ was used to determine the strength of the consensus. A $C V$ less than or equal 0.50 would indicate a strong degree of consensus among the panelists (English $\&$ Kernan, 1976). The data collected in this round would then be used to report the findings of the panelists regarding the research objectives. If the standard had a mean score less than 3.51, an $I Q R$ greater than 2.0 , or a $C V$ higher than 0.50 , it did not meet group consensus and was discarded as a standard that could be used to identify a high-quality postsecondary trade and industrial program.

\section{Findings}

Round 1. The criteria for the panelists included postsecondary administrators responsible for trade and industrial education programs at their institutions. Using a variety of resources including Web searches and professional organization membership rosters, a list was compiled of community colleges across the United States that had multiple trade and industrial education programs. Then the administrative directors of these programs were also identified. Invitations were sent out to 76 potential panelists, and a total of 16 administrators agreed to participate. The panelists were confirmed and the trade and industrial program areas they were responsible for were recorded with two panelists representing each Career Cluster including (a) Architecture and Construction, (b) Arts, Audio/Visual Technology, and Communications, (c) Government and Public Administration, (d) Human Services, (e) Information Technology, (f) Law, Public Safety, 
Correction, and Security, (g) Manufacturing, and (h) Transportation, Distribution, and Logistics (Association of Career and Technical Education, 2021, para. 4).

In Round 1,13 out of $16(81 \%)$ surveys that were distributed were completed and returned by the requested date. One panelist representing the transportation cluster failed to submit a response to Round 1. Two panelists, one representing architecture and one representing manufacturing, submitted incomplete surveys. These surveys contained the specific demographic information but did not include any standards or descriptions. After requests for completion of the survey failed, these three panelists were withdrawn from the study leaving 13 panelists.

The first section of the Round 1 survey revealed that many of the panelists were responsible for multiple trade and industrial clusters. Results of the areas represented can be seen in Table 1. The number of years in their position can be seen in Table 2.

\section{Table 1}

Panel Member Area of Responsibility by Subject Area

\begin{tabular}{lc}
\hline Subject Area & \# Of Responses \\
Architecture \& Construction & 7 \\
& \\
Arts, A/V Technology, \& Communications & 6 \\
Government \& Public Administration & 2 \\
Human Services & 5 \\
Information Technology & 5 \\
Law, Public Safety, Correction, \& Security & 5 \\
Manufacturing & 7 \\
Transportation, Distribution, \& Logistics & 10 \\
\hline
\end{tabular}

Note: Participants were permitted to select more than one subject area for which they administered.

The second section of the Round 1 survey asked the panelists to provide two standards and their related descriptions that can be used to design and assess a high-quality postsecondary trade and industrial education program. The 13 panelists submitted a total of 26 standards and descriptions that can be seen in Appendix A. Results from Round 1 were then provided to the review board, and responses were reviewed and categorized by similarities. This reduced the number of standards from 26 to 6 .

Table 2

Number of Years as an Administrator of Postsecondary Trade and Industrial Programs

\begin{tabular}{lc}
\hline Number of Years & \# Of Responses \\
\hline $0-5$ & 1 \\
$6-10$ & 6 \\
$11-15$ & 1 \\
$16-20$ & 3 \\
21 or more & 2 \\
\hline
\end{tabular}


The review board also developed common descriptions for each standard. The review board indicated there were several standards that had similar themes, such as curriculum, faculty qualifications, and meeting industry standards. Appendix B shows the compiled list that was returned to the researchers in preparation for Round 2.

Round 2. In Round 2, each panelist was asked to review the categorized list of six standards from the review board and was asked to provide additional standards that they felt may have been missed in Round 1. An e-mail was sent to the 13 panelists along with directions. All 13 panelists responded to this round $(100 \%)$. Six panelists validated the categorized list as it was presented to them. Seven panelists provided additional standards and descriptions. With this input, a revised list consisting of 17 standards and descriptions was compiled in preparation for Round 3. The researchers edited the standards and descriptions using the same method used earlier by the review board. Appendix $\mathrm{C}$ shows the updated list of standards and descriptions.

Round 3. Round 3 was designed to initiate the process of gaining consensus from the panelists regarding the standards and their related descriptions. Panelists were sent e-mails along with a copy of the revised list of standards. They were asked to rate their level of agreement on how each standard can be used to design and assess a high-quality postsecondary trade and industrial education program using a five-point Likert scale. The replies were then translated to a numeric value (strongly agree $=5$ points, agree $=4$ points, uncertain $=3$ points, disagree $=2$ points, strongly disagree $=1$ point). Descriptive statistics were used to determine the level of agreement amongst the panelists regarding each standard. The mean score represented the average of the level of agreement, and the median described the central numeric value of the responses. The standard deviation represented the dispersion of the responses. A lower standard deviation would indicate a greater consensus amongst the panelists. The interquartile range was used to determine the strength of the consensus among the panelists. All 13 panelists (100\%) provided feedback on the survey for each standard. Results can be found in Table 3.

Table 3

\begin{tabular}{|c|c|c|c|c|c|c|}
\hline Item & Standards & $n$ & $M$ & $M d n$ & $S D$ & $I Q R$ \\
\hline 1 & Academic Integration & 13 & 4.38 & 5.00 & 0.87 & 1.00 \\
\hline 2 & Advisory Committee & 13 & 4.69 & 5.00 & 0.48 & 1.00 \\
\hline 3 & Curriculum & 13 & 4.00 & 4.00 & 1.08 & 1.00 \\
\hline 4 & Employer Feedback & 13 & 4.69 & 5.00 & 0.48 & 1.00 \\
\hline 5 & Faculty Qualifications & 13 & 4.23 & 4.00 & 0.83 & 1.00 \\
\hline 6 & Meaningful Employment & 13 & 4.38 & 5.00 & 0.96 & 1.00 \\
\hline 7 & Placement Rates & 13 & 3.77 & 4.00 & 1.09 & 2.00 \\
\hline 8 & Program Design & 13 & 4.54 & 5.00 & 0.88 & 1.00 \\
\hline 9 & Program Review & 13 & 4.38 & 4.00 & 0.65 & 1.00 \\
\hline 10 & Safety & 13 & 4.92 & 5.00 & 0.28 & 0.00 \\
\hline 11 & Soft Skills & 13 & 4.85 & 5.00 & 0.38 & 0.00 \\
\hline 12 & Student Achievement of Industry Credentials & 13 & 4.69 & 5.00 & 0.48 & 1.00 \\
\hline 13 & Student Advancement & 3 & 3.46 & 4.00 & 0.88 & 1.00 \\
\hline 14 & Student Assessment & 13 & 4.69 & 5.00 & 0.48 & 1.00 \\
\hline 15 & Student Remediation & 13 & 4.31 & 4.00 & 0.63 & 1.00 \\
\hline 16 & Student Retention & 13 & 4.23 & 4.00 & 0.44 & 0.00 \\
\hline 17 & Tools and Equipment & 13 & 4.69 & 5.00 & 0.48 & 1.00 \\
\hline
\end{tabular}


Round 4. To begin Round 4, panelists were sent an e-mail with a copy of the list of standards developed in Round 2 and rated in Round 3. They were also given the descriptive statistics from Round 3 and their own individual responses. Panelists were asked to re-rate their level of agreement on how each standard can be used to design and assess a high-quality postsecondary trade and industrial education program using the same five-point Likert scale from Round 3. All 13 remaining panelists responded to the survey for a $100 \%$ response rate.

As Round 4 was designed to establish consensus amongst the panelists, the coefficient of variance $(\mathrm{CV})$ would be calculated for each standard along with the mean, median, standard deviation, and interquartile range. A $C V$ less than or equal to 0.50 and an $I Q R$ less than or equal to 2.0 would indicate consensus has been reached among the panelists. As with prior rounds, a mean score of 3.50 would need to be maintained to indicate consensus. The results of Round 4 can be found in Appendix D.

Each of the 17 standards that had subsisted through the first three rounds was analyzed. Standards were examined to determine if they had achieved a Round 4 mean $(M)$ greater than 3.50, a median $(M d n)$ greater than or equal to 4.00, a standard deviation $(S D)$ less than 1.00 , an interquartile range $(I Q R)$ less than or equal to 2.0, and a coefficient of variance $(C V)$ less than 0.50 . Each of the remaining standards met these minimum criteria, resulting in a consensus by the panelists for all 17 standards, as shown in Table 4.

\section{Table 4}

\begin{tabular}{clcccccc}
\multicolumn{2}{l}{ Round 4 Summary of Standards } & & & & & \\
\hline Item & Standards & $n$ & $M$ & $M d n$ & $S D$ & $I Q R$ & $C V$ \\
\hline & & & & & & & \\
1 & Academic Integration & 13 & 4.69 & 5.00 & 0.48 & 1.00 & 0.10 \\
2 & Advisory Committee & 13 & 4.85 & 5.00 & 0.38 & 0.00 & 0.08 \\
3 & Curriculum & 13 & 4.15 & 4.00 & 0.80 & 1.00 & 0.19 \\
4 & Employer Feedback & 13 & 4.69 & 5.00 & 0.48 & 1.00 & 0.10 \\
5 & Faculty Qualifications & 13 & 4.38 & 4.00 & 0.51 & 1.00 & 0.12 \\
6 & Meaningful Employment & 13 & 4.46 & 5.00 & 0.66 & 1.00 & 0.15 \\
7 & Placement Rates & 13 & 3.92 & 4.00 & 0.95 & 2.00 & 0.24 \\
8 & Program Design & 13 & 4.77 & 5.00 & 0.44 & 0.00 & 0.09 \\
9 & Program Review & 13 & 4.38 & 4.00 & 0.65 & 1.00 & 0.15 \\
10 & Safety & 13 & 4.92 & 5.00 & 0.28 & 0.00 & 0.06 \\
11 & Soft Skills & 13 & 4.92 & 5.00 & 0.28 & 0.00 & 0.06 \\
12 & Student Achievement of Industry & 13 & 4.54 & 5.00 & 0.66 & 1.00 & 0.15 \\
& Credentials & & & & & & \\
13 & Student Advancement & 13 & 3.62 & 4.00 & 0.77 & 1.00 & 0.21 \\
14 & Student Assessment & 13 & 4.77 & 5.00 & 0.44 & 0.00 & 0.09 \\
15 & Student Remediation & 13 & 4.23 & 4.00 & 0.60 & 1.00 & 0.14 \\
16 & Student Retention & 13 & 4.23 & 4.00 & 0.44 & 0.00 & 0.10 \\
17 & Tools and Equipment & 13 & 4.77 & 5.00 & 0.44 & 0.00 & 0.09 \\
\hline
\end{tabular}

Each of the 17 subsisting standards was analyzed. Standards were examined to determine if they had achieved a Round 4 mean $(M)$ greater than 3.50, a median $(M d n)$ greater than or equal to 4.00 , a standard deviation $(S D)$ less than 1.00, an interquartile range $(I Q R)$ less than or equal to 2.0, and a coefficient of variance $(C V)$ less than 0.50 . Each of the 17 standards met these minimum criteria, resulting in consensus. 


\section{Discussion and Conclusion}

The purpose of this study was to develop standards that can be used for establishing exceptional postsecondary trade and industrial education programs. These standards could then be used to design, develop, and assess trade and industrial education programs. Postsecondary institutions can develop the high-quality training programs that meet these standards to produce better skilled workers needed by employers.

There are limitations to this study. First, the panelists were administrators of postsecondary trade and industrial programs. The perceptions of business and industry representatives, faculty, and students were not directly included. Second, while trade and industrial subject areas can vary greatly, it presupposes that a common set of standards can be developed that are applicable to each of the trade and industrial subject areas.

The panelists identified resulting standards, four of which could appropriately be categorized under the topics of advisory committee, curriculum, faculty qualifications, and tools and equipment. The same four standards are used by the National Automotive Technicians Education Foundation (NATEF, 2012) to accredit secondary and postsecondary automotive technology programs. Once the occupationally specific standards have been stripped away from the American Council for Construction Education's (ACCE, 2011) non-degree recognition program standards, what remains is also consistent with the results of this study. This is also consistent with Mullin (2012), who stated that the assessment model for workforce development training has metrics that can be applied to the evaluation of educational programs. Finally, the standards developed align well with the National Research Center for Career and Technical Education's (National Dissemination Center for Career and Technical Education, 2001) critical factors for identifying exemplary CTE programs.

The standards needed to have descriptions to explain the function of the standard so that the assessment process could be properly followed. Therefore, $\mathrm{RO}_{2}$ was to develop descriptors that can be used to assess achievement of high-quality postsecondary trade and industrial education programs. The panelists developed the descriptions and came to a consensus regarding all 17 standards, as shown in Appendix D. Once again, all eight trade and industrial Career Cluster areas had representation on the panel. Because these 13 panelists were able to come to consensus on these standards and descriptors, this indicates that the results from the study can be applied to any or all postsecondary trade and industrial programs. Had each panelist's perspectives not been represented in the standards, then consensus could not have been achieved (Krechmer, 2006).

The descriptions from this study can also be found in notable literature related to trade and industrial education. The Carl D. Perkins Act of 2006 set performance indicators for postsecondary schools that align with the findings in this study. The descriptions for program design, student achievement of industry credentials, and student advancement align with the Perkins Act (Brustein, 2006). Some of the descriptions in the study mirror Prosser's sixteen theories of vocational education. The descriptions for faculty qualifications, meaningful employment, program design, and tools and equipment align with Prosser's theories (Gordon, 2014). As businesses need more skilled workers, the demand for trade and industrial education programs will increase. Research studies such as this one can help outline the structure and assessment methods for high-quality programs that meet industry needs. 


\section{Recommendations}

Some postsecondary trade and industrial programs struggle to produce qualified workers for their related industry. The existing programs deliver the curriculum, but do not meet the needs of their local businesses. For postsecondary administrators responsible for trade and industrial programs, this study can provide the framework they can use to assess their existing programs. Using the standards and descriptions developed by the panelists, the postsecondary institution can assess their current programs. School administrators can provide an annual report that describes the success of a program based on the standards. If the program is currently not meeting the standard, the administration, along with the faculty and local businesses, can address the issues and make improvements based on the descriptions attached to the standard. Once the changes have been implemented, the administrator, faculty, businesses, and students can provide input through a review process that utilizes the descriptions of the specific standards to ensure the program is of high quality.

A program advisory committee can conduct an independent assessment of the program using the standards. The assessment by local businesses can be used to inform the program administrator of the strengths and weakness of the program. This may provide an opportunity to make recommendations that can lead to a high-quality postsecondary trade and industrial education program.

Postsecondary institutions are sometimes challenged with meeting industry needs that they are not currently serving. For the administrator who must oversee the development of a new program to meet these needs, the results of this study can provide a framework that they can use to develop the program. The new program structure can be created using the standards, with the related program requirements (faculty, equipment, curriculum, etc.) developed using the descriptions provided. Once the program has been launched and given time to develop, the descriptions can be used to assess the program's effectiveness in the same way an existing program would be assessed.

While these standards can be applied to any program, an administrator must be mindful of existing program accreditation standards that may exist within the specific trade. The findings from this study are not intended to be a replacement for existing standards, but rather must work in harmony with them. There is no anticipation that these standards will conflict with existing credentialing or industry standards, as the panelists assuredly took this into consideration while developing this framework. However, it is quite possible that any program utilizing these standards may add occupationally specific criteria to them.

Finally, additional studies should be carried out to implement such standards into trade and industrial programs. While the standards generated from this study are consistent with many other national and international standards, as noted above, implementation of such standards will allow early adopters to include instructor feedback. Such feedback may be valuable in helping to address content specific issues based on everyone's content area of expertise. specific criteria, they should be able to address and trade and industrial program.

\section{Summary}

The researchers identified a group of current postsecondary trade and industrial administrators. They were invited to be expert panelists as part of a Delphi study to develop a set of standards that can be used in postsecondary institutions as a framework for a high-quality 
trade and industrial education program. Round 1 of the Delphi study allowed participants to openly identify two standards for trade and industrial education. Three additional rounds shaped the evolution of the original standards, adding items to the list, removing some, and editing others. The result was a set of 17 standards that may be used as a framework for determining a high-quality postsecondary trade and industrial education program.

\section{References}

Abeysekera, I. (2006). Issues relating to designing a work-integrated learning program in an undergraduate accounting degree program and its implications for the curriculum. Asia-Pacific Journal of Cooperative Education, 7(1), 7-15. https://www.ijwil.org/files/APICE 07 1 7 15.pdf

American Council for Construction Education. (2011). Non degree recognition program standards. http://www.acce-hq.org/images/uploads/Program Standards 092614.pdf

American Industrial Arts Association. (1985). Standards for technology education programs. GoodheartWillcox.

Anderson, A., \& Kosarek, D. (1997). Critical issues in the evolving relationship between business industry and postsecondary education. Center for Occupational Research and Development. http://www.cord.org/uploadedfiles/Critical\%20Issues.pdf

Aragon, A., Woo, H-J., \& Marvel, M. R. (2004). Analysis of the integration of skill standards into community college curriculum. National research center for career and technical education, 44(2). University of Minnesota. https://files.eric.ed.gov/fulltext/ED492350.pdf

Arthur, W. B., Durlauf, S. N., \& Lane, D. (Eds.). (1988). The economy as an evolving complex system Addison-Wesley Publishing Co.

ASE (2018, December 18, 2020). ASE (National Institute for Automotive Service Excellence). https://www.automechanicschooledu.org/ase/

Association of Career and Technical Education. (2021, November 22, 2021). Trade and industrial education division. https://www.acteonline.org/about/structure/divisions/trade-and-industrialeducation-

division/\#: : :text=The $\% 20$ ACTE $\% 20$ Trade\%20and\%20Industrial\%20Education\%20Division $\% 20$ is, Architecture $\% 20$ and $\% 20$ Construction $\% 20$ Arts $\% 2 \mathrm{C} \% 20 \mathrm{~A} \% 2 \mathrm{FV} \% 20 \mathrm{Technology} \% 20$ and $\% 20$ Communications

Bailey, T., Kienzl, G., \& Marcotte, D. E. (2004). The return to a sub-baccalaureate education: The effects of schooling, credentials, and program of study on economic outcomes. National Assessment of Vocational Education, U.S. Department of Education. Retrieved from http://www2.ed.gov/rschstat/eval/sectech/nave/subbac-ed.pdf

Baird, M., Bozick, R., \& Zaber, M. (2020, December). Beyond traditional academic degrees: The labor market returns to occupational credentials. ERIC (Working Paper \#WR1299). https://doi.org/10.7249/WR1299

Beltram, P. (2011). Making assessing CTE programs meaningful. Techniques, 86(5), 10-11.

Biden, J. (2011). The White House summit on community colleges: Building American skills by strengthening community colleges. https://obamawhitehouse.archives.gov/sites/default/files/uploads/community college summit re port.pdf

Bragg, D. D. (2001). Opportunities and challenges for the new vocationalism in American community colleges. New Directions for Community Colleges, 115, 5-15. https://doi.org/10.1002/cc.26

Brown, B. L. (1997). Quality improvement awards and vocational education assessment. ERIC Clearinghouse on Adult Career and Vocational Education. http://www.ericdigests.org/19981/awards.htm 
Journal of Research in Technical Careers

Trade and Industrial Education Program Standards

Brown, K. (2018). Powerful partners: Businesses and community colleges. National Skills Coalition. https://library.naswa.org/doi/10.5555/20.500.11941/1927

Bryant, D. (2014). Factors and processes that impact use of Utah Community/State College contract training: A mixed methods study. Community College Journal of Research and Practice, 38(1), 38-49. DOI: $10.1080 / 10668926.2010 .532456$

Brustein, M. (2006). Perkins Act of 2006. The official guide. Association for Career and Technical Education.

Carl D. Perkins Career and Technical Education Act of 2006. Pub. L. 109-270, § 120 Stat. 683 (2006).

Center for Global Standards Analysis (2008). The strategic value of standards education (Purcell, Ed.). Author.

Council on Occupational Education. (2012). Handbook for programmatic accreditation. Atlanta, GA: Council on Occupational Education. http://www8.spinen.net/councilorg/files/downloads/2012/08/2012-Programmatic-Handbook-w-Covers.pdf

Dougherty, K. J., \& Bakia, M. F. (2000). Community colleges and contract training: Content, origins, and impact. Teachers College Record, 102(1), 197-243.

English, J. M., \& Kernan, G. L. (1976). The prediction of air travel and aircraft technology to the year 2000 using the Delphi method. Transport Research, 10, 1-8. https://doi.org/10.1016/00411647(76)90094-0

Gaal, J., \& Trafton, S. (2009). The PSI score card: Determining when to close a CTE program. Techniques, 84(6), 44-46.

Gauthier, T. (2020). A renewed examination of the stigma associated with community college career and technical education. Community College Journal of Research and Practice, 44, 1-15.

DOI: $10.1080 / 10668926.2020 .1758835$

Gordon, H. R. (2014). The history and growth of career and technical education in America. Waveland Press.

Grigal, M., Dwyre, A., Emmett, J., \& Emmett, R. (2012). A program evaluation tool for dual enrollment transition programs. Teaching Exceptional Children, 44(5), 36-45.

Grubb, W. N. (1996). Working in the middle: Strengthening education and training for the mid-skilled labor force. Jossey-Bass.

Grubb, W. N. (1999). Edging towards effectiveness: Examining postsecondary occupational education. United States Department of Education. https://www2.ed.gov/rschstat/eval/sectech/nave/grubb.pdf

Hayek, F. A. (1973). Law, legislation, and liberty: Rules and order. Routledge \& Kegan Paul.

Hereford, S. (2005). Promising pathways: Training low-skilled adults. Community College Journal, 76(1), 46-49.

Hirschy, A. S., Bremer, C. D., \& Castellano, M. (2011). Career and technical education (CTE) student success in community colleges: A conceptual model. Community College Review, 39(3), 296318. doi:10.1177/0091552111416349

Honderich, T. (1995). The Oxford companion to philosophy. Oxford University Press.

Hyslop, A. (2018). Perkins V: The official guide ( $5^{\text {th }}$ ed.). Association for Career and Technical Education.

Izadi, M, Kashef, A. E., \& Stadt, R. W. (1996). Quality in higher education: Lessons learned from the Baldrige Award, Deming Prize, and ISO 9000 Registration. Journal of Industrial Teacher Education, 33(2), 1-13. http://scholar.lib.vt.edu/ejournals/JITE/v33n2/izadi.html

Jacobs, J. (2001). What is the future for post-secondary occupational education? Journal of Vocational Education Research, 26(2), 172-205.

Johnson, M., Bashay, M., \& Bergson-Shilcock, A. (2019). The roadmap for racial equality: An imperative for workforce development advocates. National Skills Coalition. https://files.eric.ed.gov/fulltext/ED603236.pdf

Kerka, S. (2002). Effective advisory committees. Career and Technical Education National Dissemination Center, (Fast Fasts No. 17). 
Trade and Industrial Education Program Standards

Kosloski, M., \& Ritz, J. (2016). Research needs: Career and technical education. Career and Technical Education Research 41(2), 117-140. doi:10.5328/cter41.2.107

Krechmer, K. (2006). International standardization as a strategic tool: Commended papers from the IEC Centenary Challenge, p. 143-154. Geneva, Switzerland: International Electrotechnical Commission. http://www.isology.com/pdf/IECChallenge2006.pdf

Lambeth, J. M., Joerger, R. M., \& Elliot, J. (2009). Implication for focusing research on career and technical education and workforce development. Career and Technical Education Research, $34(3), 137-153$.

Landeta, J. (2005). Currently validity of the Delphi method in social sciences. Technological Forecasting \& Social Change, 73, $467-482$.

Lohman, E. M., \& Dingerson, M. R. (2005). The effectiveness of occupational-technical certificate programs: Assessing student career goals. Community College Journal of Research and Practice, 29, 339-355. doi:10.1080/10668920590911850

Losh, C. L. (2000). Using skill standards for vocational-technical education curriculum development. Ohio State University. http://www.eric.ed.gov/PDFS/ED440295.pdf

Lundquist, P. A. (2000). Get your automotive program nationally certified. Tech Directions, 59(6), 15-16.

Kelly, S., \& Price, H. (2009). Vocational education: A clean slate for disengaged students? Social Science Research, 38(4), 810-825. https://doi.org/10.1016/j.ssresearch.2009.05.002

Kim, E. H., Flack, C. B., Parham, K., \& Wohlstetter, P. (2021). Equity in secondary career and technical education in the United States: A theoretical framework and systematic literature review. Review of Educational Research, 93(3), 356 - 396. https://doi.org/10.3102/0034654321995243

McCaslin, N. L., \& Headley, W. S. (1993). A national study of approved state systems of performance measures and standards for vocational education. Ohio State University. http://eric.ed.gov:80/ERICWebPortal/contentdelivery/servlet/ERICServlet?accno=ED360474

Merkley, R. J., \& Johnston, G. H. (2007). State approval policies and procedures for postsecondary career and technical education. St. Paul, MN: National Research Center for Career and Technical Education. http://nrccte.org/sites/default/files/publication-files/state_approval_policies-cc.pdf

Mullin, C. M. (2012). Understanding the workforce outcomes of education. New Directions for Institutional Research, 153, 75-88. doi:10.1002/ir.20008

National Automotive Technicians Education Foundation. (2012). NATEF program accreditation standards. National Automotive Technicians Education Foundation. http://www.natef.org

National Dissemination Center for Career and Technical Education. (2002). What makes a careertechnical education program exemplary? A rubric for secondary-level programs. National Research Center for Career and Technical Education. Retrieved from http://www.azed.gov/career-technical-education/files/2011/06/exemplaryprogramrubric.pdf

National Dissemination Center for Career and Technical Education (2001). Attributes and Characteristics of Exemplary, Leading, and Innovative, Career and Technical Education Teacher Preparation Programs. National Research Center for Career and Technical Education. http://files.eric.ed.gov/fulltext/ED478955.pdf

No Child Left Behind Act of 2001, Pub. L. 107-110, § 107, 115 Stat. 1425 (2002).

O'Banion, T. (2019) A brief history of workforce education in community colleges. Community College Journal of Research and Practice, 43(3), 216-223. https://doi.org/10.1080/10668926.2018.1547668

Parente, R., \& Anderson-Parente, J. (2011). A case study of long-term Delphi accuracy. Technological Forecasting and Social Change. 78(9), 1705-1711. https://doi.org/10.1016/j.techfore.2011.07.005

Powell, C. (2003). The Delphi technique: Myths and realities. Journal of Advanced Nursing, 41(4), 376382.

Roberts, A. S. (2013). Preferred instructional design strategies for preparation of pre-service teachers of integrated STEM education (Doctoral dissertation). Available from ProQuest Dissertations and Theses database. (UMI No. 3576657)

Rojewski, J. W. (2002). Preparing the workforce for tomorrow: A conceptual framework for career and 
Trade and Industrial Education Program Standards

technical education. Journal of Vocational Education Research, 27(1), 7-34.

Schmidtke, C. (2012). The American community college. In A. Barabasch \& F. Rauner (Eds.), Work and education in America: The art of integration (pp. 53-75). Springer.

Silverberg, M., Warner. E., Fong, M., \& Goodwin, D. (2004). National assessment of vocational education: Final report to Congress. United States Department of Education. http://www2.ed.gov/rschstat/eval/sectech/nave/navefinal.pdf

Soares, L. (2010). The power of the Education-Industry Partnership. Center for American Progress. https://www.americanprogress.org/issues/economy/reports/2010/10/04/8518/the-power-of-theeducation-industry-partnership/

Stecher, B. M., Hanser, L. M., Rahn, M. L., Levesque, K., Klein, S. G., \& Emanual, D. (1995). Improving performance measures and standards for workforce education (Report No. MDS-821). National Center for Research in Vocational Education. http://www.nrccte.org/sites/default/files/publicationfiles/improving_performance_measues.pdf

Stitt-Gohdes, W. L., \& Crews, T. B. (2004). The Delphi technique: A research strategy for career and technical education. Journal of Career and Technical Education, 20(2), 55-67. http://scholar.lib.vt.edu/ejournals/JCTE/v20n2/stitt.html

Symonds, W. C., Schwartz, R. B., \& Ferguson, R. (2011). Pathways to prosperity: Meeting the challenge of preparing young Americans for the $21^{\text {st }}$ century. Harvard Graduate School of Education. http://www.gse.harvard.edu/news events/features/2011/Pathways to Prosperity Feb2011.pdf

Torraco, R. J. (2008). Preparation for midskilled work and continuous learning in nine community college occupational programs. Community College Review, 35(3), 208-236. doi:10.1177/0091552107310119

United States Department of Education. (2012). Scaling the community college summits: Challenges, solutions, and commitments. United States Department of Education. http://www2.ed.gov/about/offices/list/ovae/pi/cclo/regional-summit-proceedings.pdf

Wentling, T. L. (1980). Evaluating occupational education and training programs. Griffon Press.

Williams, P., \& Webb, C. (1994). The Delphi technique: A methodological discussion. Journal of Advanced Nursing, 19, 180 - 186.

Willis, J. L. (1995). Skill standards: A primer (Series No. RERS 1995). U.S. Department of Labor. http://wdr.doleta.gov/opr/fulltext/95-voluntary.pdf

$\mathrm{Xu}, \mathrm{D} ., \quad \&$ Ran, F. X. (2020). Noncredit education in community college: Students, course enrollments, and academic outcomes. Community College Review, 48(1), 77-101.

Yarnall, L. (2014). Meeting 2020 workforce goals: The role of industry-college collaboration and goals for instructional design. Community College Journal of Research and Practice, 38(2-3), 250-260.

Zinser, R. W. (2003). Evaluation of a community college technical program by local industry. Journal of Industrial Teacher Education, 40(2), 51-64. http://scholar.lib.vt.edu/ejournals/JITE/v40n2/zinser.html 


Standard
$85 \%$ of students enrolled in workforce
programs will be retained from the first
quarter of enrollment to the second quarter
of enrollment
Advisory committee is made up of industry
reps from labor and management

Connection with industry norms

Contextualized learning

Curriculum and instructional planning

Curriculum relevance

Demonstrate knowledge of content areas and familiarity with state Department of Education pre-kindergarten standards

\section{APPENDIX A}

\section{Description}

Of any starting cohort of students in any workforce program at least $85 \%$ will successfully transition from first term to second term.

To ensure that programs are relevant to today's economy, at least $50 \%$ of the committee needs to be from management (w/ hiring/firing capacity within their firms) and chaired by a management rep.

Where applicable, course content should replicate and/or satisfy industry recognized credentials or oversight groups.

Student learning is conducted in an environment like the "real world" experience the student will enter upon completion of the program.

The program is properly designed to prepare students for entry into the occupation or trade.

The program's curriculum should be based on task analysis of actual professionals working in that job.

Implies the program uses the current state standards to build a program and assess the student understanding of external standards. 
Trade and Industrial Education Program Standards

Appendix A (continued)

Standard

Demonstrate knowledge of theories of human growth, development, and learning related to children, from birth to age eight.

Demonstrated learning outcomes

Evidence-based teaching strategies

Gainful employment

Independent problem solving

Industry credentials

Industry recognized curriculum

Instructional faculty/staff

Instructors must have balanced technical and academic backgrounds
Description

The theory informs the curriculum and is woven throughout courses so that students provide the appropriate activities etc. for the children in the childcare centers.

Each course will provide an environment for the student to demonstrate the theory of the applicable subject matter.

A method of teaching that incorporates recent research findings and "best practices" into the course of study

Upon completion of the program, at least $90 \%$ of the students find gainful employment in an occupation directly related to the program in which they were enrolled.

Ability to come up with problem formulation, test problems, and test for solutions.

The program content is consistent with industry credential requirements.

What industry wants.

The instructional faculty/staff can proficiently and competently provide students with quality instruction for entry into the occupation or trade.

To ensure that teachers act as professionals, the system must require a balance of the following factors: no less than 9 years of certified field experience, no less than a bachelor's degree from an accredited institution and obtain the applicable state teacher's (lifetime/permanent) license. 
Trade and Industrial Education Program Standards

Appendix A (continued)

\begin{tabular}{ll}
\hline Standard & Description
\end{tabular}

Laboratory instruction

Promote teaching and learning excellence through the preparation and certification of educators.

\section{Qualified instructors}

Soft skills

Team collaboration

Up to date equipment

Workforce program advisory committees rate the program graduates as "workforce ready"
Laboratories should be equipped with the most current industry equipment and tools to facilitate learning. The required equipment and tools should be identified with the support of industry.

Address the quality of professional and technical skills for Career \& Technical Education (CTE) teachers by establishing high quality standards for preparing teachers and requiring that teachers attain appropriate industry standards certification.

Instructors should have (as a minimum) an AAS in the field they are teaching and a minimum number of years practicing in the industry.

In addition to the technical skills related to completing specific tasks on the job, the program provides opportunities for students to master soft skills, such as punctuality, quality of work, communicating and collaborating with others, etc.

Ability to know when to use a team for problem-solving or implementing solutions.

Equipment used in field, current equipment.

In a structured survey of a program's advisory committee the aggregate average of questions answered indicating graduates are workforce ready will be at least $80 \%$. 
Journal of Research in Technical Careers

Journal of Research in Technical Careers

December 2021, Vol. 5, No. 2

(C) Author(s)

\section{APPENDIX B}

Categorized List of Standards by Review Board

Standard

Description

Advisory Committee is composed of representatives from the community, local industry, national sponsors, state, and national accrediting bodies

Faculty meet professional and academic qualifications

Meaningful employability

Programs are designed around industry standards

Programs are designed around industry standards (continued)

Soft skills
To ensure that programs are relevant to the economy, the committee needs to be from labor and management.

Instructors should have (as a minimum) an AAS in the field they are teaching and a minimum number of years practicing in the industry. Faculty are recognized professionals in the field, with appropriate industry standards certifications, and have expertise including best practices in delivering instruction and evaluating training.

The program content leads to long-term employment at a family sustainable wage.

Programs should be developed and continually validated in collaboration with secondary, postsecondary, and industry partners; incorporate essential knowledge and skills (e.g., academic skills, communication, and problem solving), which students must master regardless of their chosen career area.

Provide the same rigorous knowledge and skills in English and mathematics that employers and colleges expect of high school graduates; incorporate industry-recognized technical standards that are valued in the workplace; and to the extent practicable, be internationally benchmarked so that all students are prepared to succeed in a global economy.

In addition to the technical skills related to completing specific tasks on the job, the program provides opportunities for students to master soft skills, such as punctuality, quality of work, communicating and collaborating with others, etc. 
Trade and Industrial Education Program Standards

\begin{abstract}
APPENDIX C
Revised List of Standards and Descriptions for Round 3

\begin{tabular}{ll}
\hline Standard & Description \\
\hline Academic Integration & $\begin{array}{l}\text { Academic integration should provide the same rigorous knowledge and skills in } \\
\text { English and mathematics that employers and colleges expect, and to the extent } \\
\text { practicable, be internationally benchmarked so that all students are prepared to } \\
\text { succeed in a global economy. }\end{array}$ \\
& $\begin{array}{l}\text { To ensure the program is relevant to industry, an advisory committee will make } \\
\text { key recommendations regarding standards, critical competencies, technical skill } \\
\text { attainment, assessments, facilities, and equipment. The committee will be } \\
\text { comprised of applicable representatives from the community, local business and } \\
\text { industry, national sponsors, and state and national accrediting bodies. }\end{array}$
\end{tabular}

Curriculum

Employer Feedback

Faculty Qualifications

The program curriculum is designed to reflect the needs of industry and is subject to revision by the program advisory committee.

The program utilizes feedback from employers regarding the effectiveness of the training students receive and uses this feedback for program improvement.

Faculty should have as a minimum an Applied Associate of Science or equivalent degree in the field they are teaching and a minimum number of years practicing in the industry for which they teach. Faculty are recognized professionals in the field with appropriate industry certifications. They have expertise in delivering instruction that includes best practices and training evaluation. The faculty follow a professional development plan that is designed to improve their effectiveness.
\end{abstract}

Meaningful Employability

Placement Rates

Program Design

Program Review

Safety

APPENDIX C (continued)
The program content leads to long-term employment at a family sustainable wage.

The program monitors the placement rates of their students to an acceptable level as determined by the advisory committee.

Programs incorporate industry-recognized technical standards into their curriculum and training methods that are valued in the workplace and are continually validated in collaboration with secondary, postsecondary, and industry partners. Programs should be designed with lattices and ladders for student advancement opportunities.

Programs will develop an annual written review process that will be used to assess program quality and performance and make recommendations for continuous improvement.

Safety is incorporated into all aspects of the program. Facilities and equipment will be regularly inspected to maintain compliance with applicable OSHA regulations. Instructors will complete OSHA safety training as per their industry. Safety is an integral part of the program curriculum.

Standard Description




\section{Trade and Industrial Education Program Standards}

Soft Skills

Student Achievement of Industry Credential

Student Advancement

Student Assessment

Student Remediation

Student Retention

Tools and Equipment
In addition to the technical skills related to completing specific tasks on the job, the program provides opportunities for students to master soft skills, such as punctuality, quality of work, and communicating and collaborating with others.

The program prepares students to take and pass industry accepted certification and/or licensure exams.

For those students in a two-year program seeking a four-year degree, a determination will be made regarding their readiness to transfer to a four-year institution.

Student assessments must determine each student's technical skill attainment to relevant industry standards. Students should also demonstrate mastery of academic skills attainment regardless of their chosen career area.

Remediation structures are in place for students that are found needing help with being successful in the academic or technical courses.

Most students that begin a program will complete it.

The laboratories are equipped with up-to-date tools and equipment that are based upon the recommendation of the advisory committee. The equipment should be representative of what is utilized in the industry. 


\section{APPENDIX D}

Standards and Descriptions for Postsecondary Trade and Industrial Education Programs

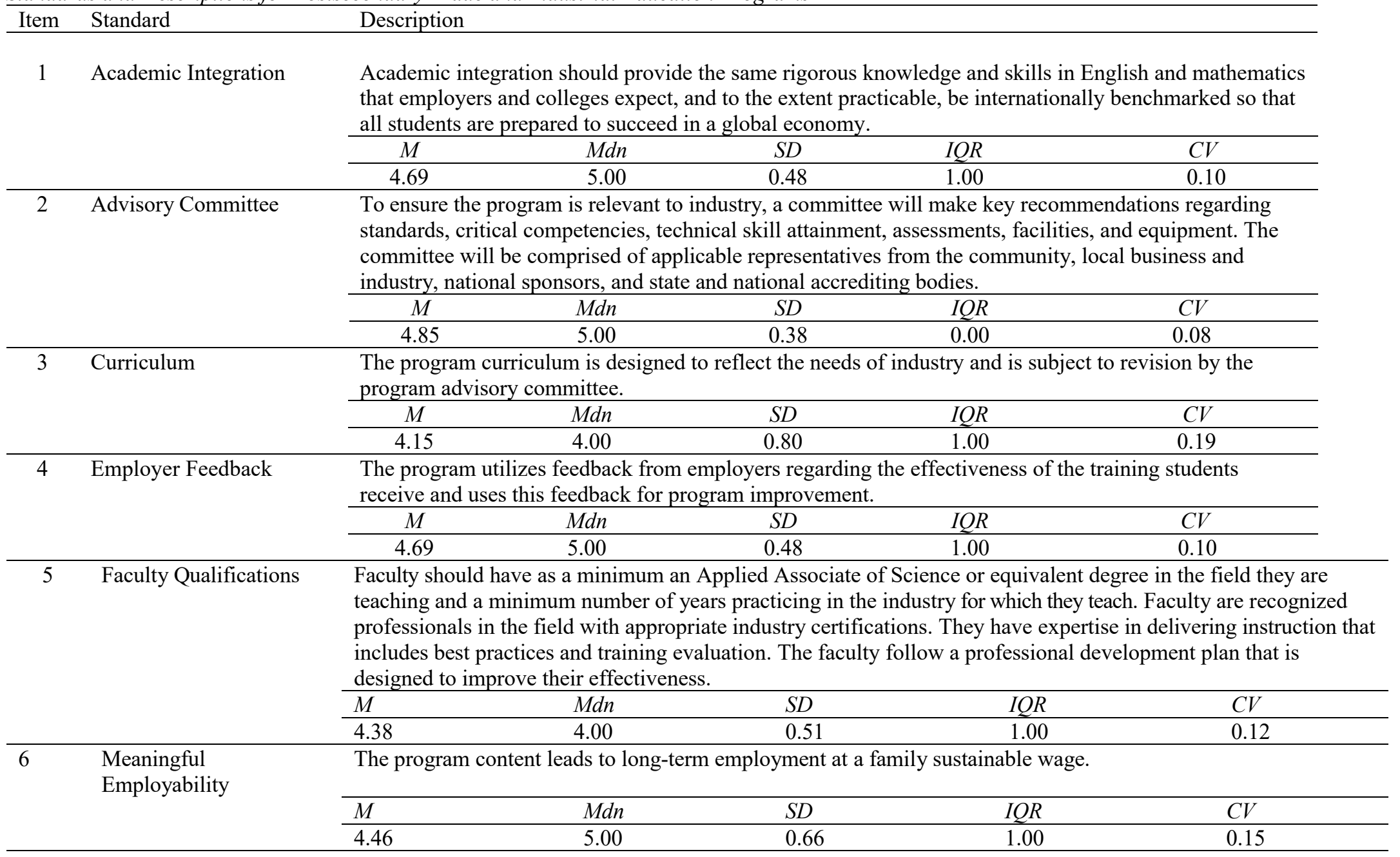


Trade and Industrial Education Program Standards

Appendix D (continued)

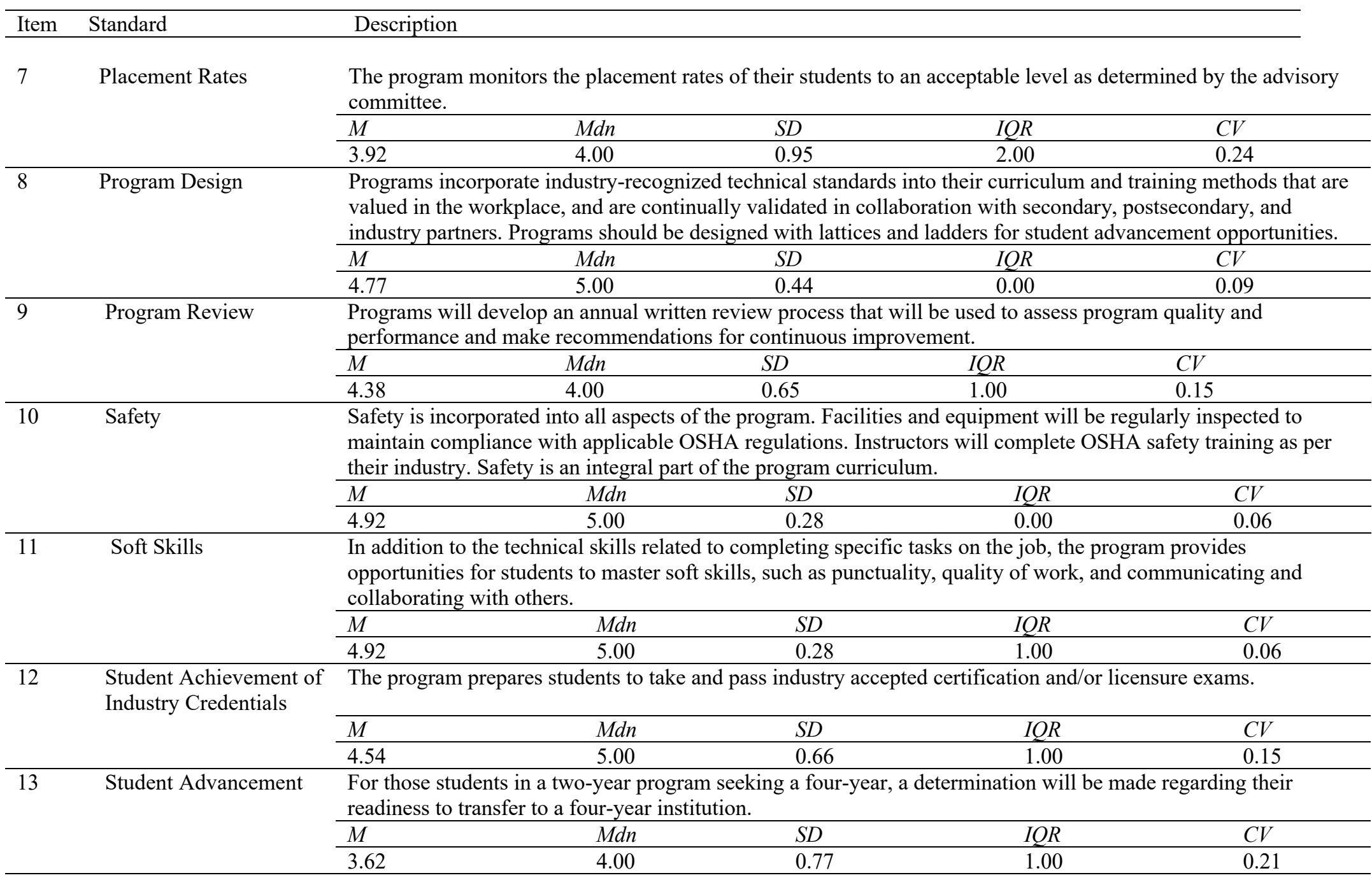


Trade and Industrial Education Program Standards

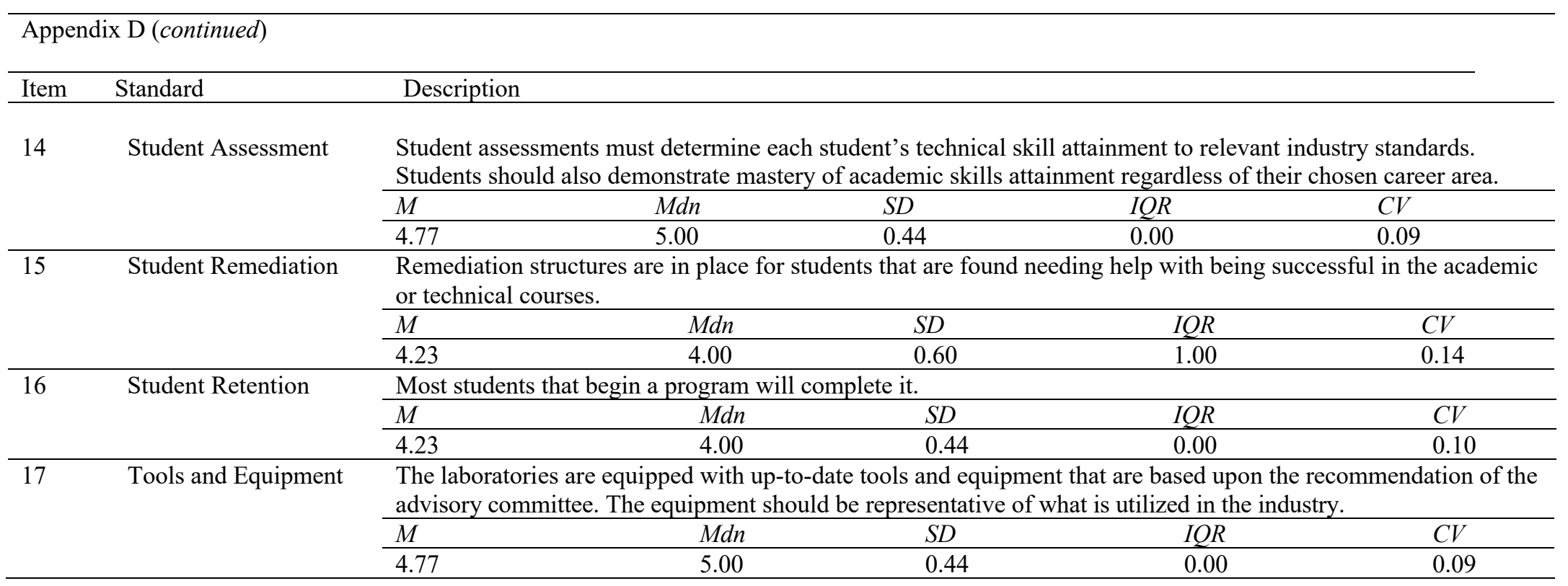

